University of Nebraska - Lincoln

DigitalCommons@University of Nebraska - Lincoln

July 1996

\title{
SPIKELET AND FLORET NAMING SCHEME FOR GRASSES WITH A SPIKE INFLORESCENCE
}

Wallace Wilhelm

University of Nebraska-Lincoln, wwilhelm1@unl.edu

Gregory S. McMaster

USDA-ARS, greg.mcmaster@ars.usda.gov

Follow this and additional works at: https://digitalcommons.unl.edu/usdaarsfacpub

Part of the Agricultural Science Commons

Wilhelm, Wallace and McMaster, Gregory S., "SPIKELET AND FLORET NAMING SCHEME FOR GRASSES WITH A SPIKE INFLORESCENCE" (1996). Publications from USDA-ARS / UNL Faculty. 93. https://digitalcommons.unl.edu/usdaarsfacpub/93

This Article is brought to you for free and open access by the U.S. Department of Agriculture: Agricultural Research Service, Lincoln, Nebraska at DigitalCommons@University of Nebraska - Lincoln. It has been accepted for inclusion in Publications from USDA-ARS / UNL Faculty by an authorized administrator of DigitalCommons@University of Nebraska - Lincoln. 


\section{SPIKELET AND FLORET NAMING SCHEME FOR GRASSES WITH A SPIKE INFLORESCENCE}

\author{
W. W. Wilhelm* and Gregory S. McMaster
}

\begin{abstract}
Effective schemes to name uniquely and define parts of grass plants allow researchers to communicate results of their experiments accurately and precisely. Naming schemes for vegetative parts of grass plants have been developed; however, no system exists to name uniquely parts of the inflorescence. In this report, we present a method to extend existing systems to name parts of grass spikes. Spikelet positions are denoted by the letter $S$ and numbered acropetally along the rachis. For example, the third spikelet position from the base of the rachis is named S3. Likewise, floret positions along the rachilla are named $\mathrm{F}$ (or $\mathrm{C}$ after fertilization) and numbered acropetally from the base to tip. The second caryopsis (floret) in the spikelet at the third spikelet position on a spike would be named $\mathrm{S3C}$. This simple scheme, when combined with the system for naming tiller, leaves, and roots, will allow all plant parts to be named uniquely. If the caryopsis in the previous example was produced on the tiller formed in the axil of the first leaf on the main stem, the complete description of the caryopsis is T1S3C2. Using this system, researchers and practitioners can communicate precisely findings on development, growth, and functional characteristics of plants and plant parts.
\end{abstract}

S IMILAR SYSTEMS for naming uniquely vegetative parts of small grains and forage grasses have been devised by Jewiss (1972) and Klepper et al. (1982) for leaves and by Jewiss (1972) for tillers. The combination of these systems, along with modification or extension by others (Fraser et al., 1982; Kirby et al., 1985; Klepper et al., 1983a; Masle, 1985; Masle-Meynard and Sebillotte, 1981; Thomson and Stokes, 1987) has produced the standard system for naming and identifying vegetative parts of small grains and forage grasses. The system is based on the concept of naming structures on a culm with a letter to designate the structure type and numbering them in the order of their appearance. That is, the first leaf on a culm is designated L1, L for leaf and 1 for the first position. The second leaf is designated L2. The

W.W. Wilhelm, USDA-ARS, 117 Keim Hall, Univ. of Nebraska, Lincoln, NE 68583-0934; Gregory S. McMaster, USDA-ARS, Great Plains Systems Res. Unit, PO Box E, Fort Collins, Colorado 80522. This paper is a joint contribution of the USDA-ARS and the Agric. Res. Division of the Univ. of Nebraska. Published as J. Series Number 11191. Received 11 July 1995.*Corresponding author (wwilhelm@unl.edu).

Published in Crop Sci. 36:1071-1073 (1996). system extends up the culm so all leaves can be named specifically. Culms, or tillers, are denoted with a $\mathrm{T}$ and defined by the number of the leaf axil in which they form, with the exception of MS, which is the first culm to appear from the seed. Primary, or first-order tillers, are formed in the axils of MS leaves and designated by one-digit numbers (e.g., T1). Second-order tillers are born in the axils of leaves on first-order tillers and are named with a $T$ and two-digit numbers (e.g., T21). The system is infinitely expandable.

The system of naming leaves acropetally along the culm can easily be extended to other vegetative organs. If the unique identity of nodes, internodes, or leaf sheaths and blades is needed, they can be named in the same manner. This system was developed to identify the major above ground vegetative structures of small grains and forage grasses. Klepper et al. (1984) expanded the scheme to include roots.

The system, as presented by Klepper et al. (1983a), has been used widely by scientists to communicate the precise vegetative organ under discussion or study (Baker et al., 1986; Krenzer et al., 1991). The naming scheme is also used in models (SHOOTGRO, MODWHT) to accurately report the existence and size of organs on the simulated plants (McMaster et al., 1991; Rickman et al., 1996; Wilhelm et al., 1993).

Allred (1982) and Allred and Columbus (1988) present concepts for delineation of grass inflorescence types and a means of applying the floral formula to grass. Klepper et al. (1983b) and Sweet et al. (1991) present numerical schemes for measuring the progression of inflorescence development. Numerous systems have been designed to assign numerical values to phenological age of culms or plants (Haun, 1973; Large, 1954; Robertson, 1968; Waldren and Flowerday, 1979; Zadoks et al., 1974). However, we know of no scheme giving unique names to reproductive structures in small grains or forage grasses. To this end, we suggest the following extension of the system described above to name uniquely reproductive structures in wheat (Triticum aestivum L.) and other grasses with spike inflorescences.

The first spikelet position at the base of the rachis, whether a spikelet is developed or not, is named S1 (S for spikelet, 1 for the basal position), the second is named S2, and so on up the spike (Fig. 1). Florets (F) are designated acropetally from the base of the rachilla. The first floret is F1, the second is F2, and so forth.

Abbreviations: F, floret; C, caryopsis; MS, main stem; S, spikelet; T, tiller. 


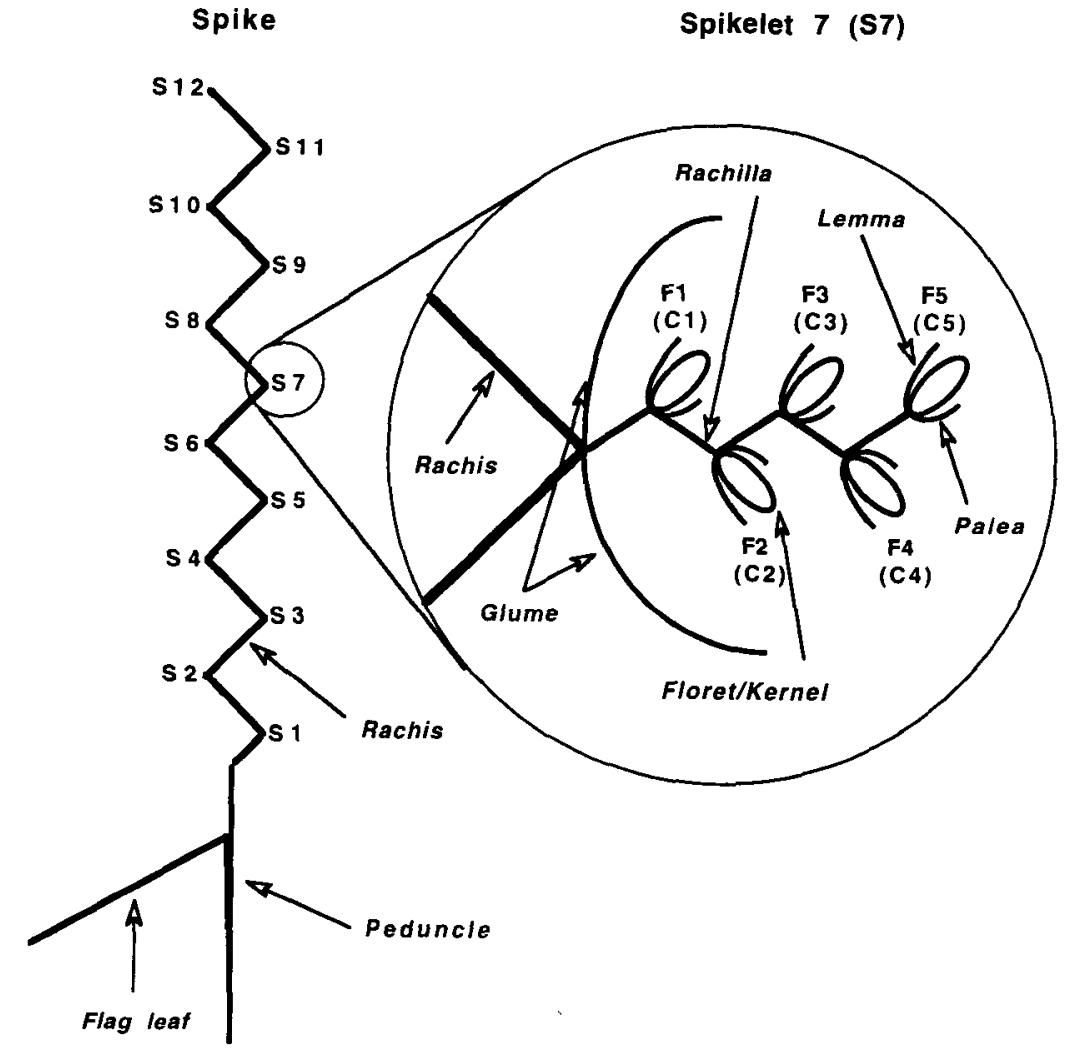

Fig. 1. Naming scheme for reproductive organs of spike inflorescences. Spikelet positions are denoted by the letter $\mathbf{S}$ and numbered acropetally along the rachis. Floret-caryopsis positions are denoted by the letters $\mathrm{F} / \mathrm{C}$ and numbered acropetally along the rachilla.

After fertilization, the letter designation for florets is changed to $\mathrm{C}$ for caryopsis.

This procedure is applicable for grasses with spike inflorescences having one spikelet per rachis node such as wheat and rye (Secale cereale L.); however, for species with more than one spikelet per rachis node [barley (Hordeum vulgare L.)], the scheme must have one additional component. By adding a lower-case letter to the spikelet position name, the specific spikelet can

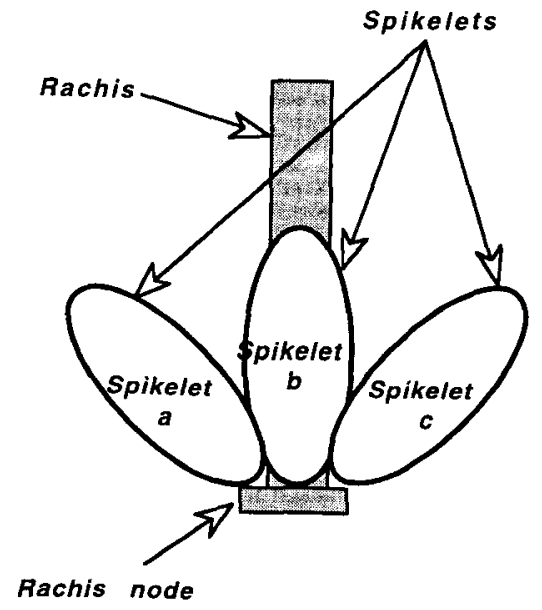

Fig. 2. Naming convention for spikes with multiple spikelets at each rachis node. Spikelets are named by adding a lower-case letter to the spikelet position number used in the basic spike naming scheme. Letters are assigned to spikelets from left to right when viewed with the rachis behind the spikelets. be named. Lettering from left to right (when viewed with the rachis behind the spikelets) multiple spikelets per spikelet position are named a, b, c, etc. (Fig. 2). All florets (caryopses) are defined as F1 because only one floret is produced per spikelet. As an example of the system in a barley plant, the caryopsis in the central spikelet at the fourth spikelet position on tiller $\mathrm{T} 1$ is named $\mathrm{T} 1 \mathrm{~S} 4 \mathrm{bCl}$. This name is correct for both 2- and 6-row barley because the central spikelet is the only one to develop in both types of barley. However, in 2-row barley, S\#a and S\#c will never have F1 or $\mathrm{C} 1$ designations because lateral spikelets do not complete development.

Unfortunately, the simplicity and utility of this system does not extend to grasses with more complex, branched inflorescences such as panicles [e.g., oat (Avena sativa L.) and rice (Oryza sativa L.)]. At this time we have not proposed a naming scheme for spikelets, florets, and caryopses on branched inflorescences.

By means of the combined systems described here for naming culms and structures, all parts on grasses with spike inflorescences can be identified with unique names. For example, T2S5C3 is the third caryopsis at the fifth spikelet position on the spike of the tiller formed in the axil of the second MS leaf. Use of this system will allow researchers to communicate accurately their findings on development, growth, and functional characteristics of all above ground plants parts in response to environmental and managerial changes. With the addition of the ideas presented by Klepper et al. (1984) for naming 
roots, all parts of grasses with spike inflorescences can be named and identified uniquely.

\section{References}

Allred, K.W. 1982. Describing the grass inflorescence. J. Range Manage. 35:672-675.

Allred, K.W., and J.T. Columbus. 1988. The grass spikelet formula: An aid in teaching and identification. J. Range Manage. 41:350351 .

Baker, J.T., P.T. Pinter Jr., R.J. Reginato, and E.T. Kanemasu. 1986. Effects of temperature on leaf appearance in spring and winter wheat cultivars. Agron. J. 78:605-613.

Fraser, J., C.T. Dougherty, and R.H.M. Langer. 1982. Dynamics of tiller populations of standard height and semi-dwarf wheats. N. Z. J. Agric. Res. 25:321-328.

Haun, J.R. 1973. Visual quantification of wheat development. Agron. J. 65:116-119.

Jewiss, O.R. 1972. Tillering in grasses-its significance and control. J. Br. Grassl. Soc. 27:65-82.

Kirby, E.J.M., M. Appleyard, and G. Fellowes. 1985. Effect of sowing date and variety on main shoot leaf emergence and number of leaves of barley and wheat. Agronomie 5:117-126.

Klepper, B., R.K. Belford, and R.W. Rickman. 1984. Root and shoot development in winter wheat. Agron. J. 76:117-122.

Klepper, B., R.W. Rickman, and R.K. Belford. 1983a. Leaf and tiller identification on wheat plants. Crop Sci. 23:1002-1004.

Klepper, B., R.W. Rickman, and C.M. Peterson. 1982. Quantitative characterization of vegetative development in small cereal grains. Crop Sci. 74:789-792.

Klepper, B., T.W. Tucker, and B.D. Dunbar. 1983b. A numerical index to assess early inflorescence development in wheat. Crop Sci. 23:206-208.

Krenzer, E.G., Jr., T.L. Nipp, and R.W. McNew. 1991. Winter wheat mainstem leaf appearance and tiller formation vs. moisture treatment. Agron. J. 83:663-667.

Large, E.C. 1954. Growth stages in cereals. Plant Pathol. 3:128129.

Masle, J. 1985. Competition among tillers in winter wheat: Consequences for growth and development of the crop. p. 33-54. In W. Day and R.K. Atkin (ed.) Wheat growth and modelling. Plenum Press, New York.

Masle-Meynard, J., and M. Sebillotte. 1981. Heterogeneity of a winter wheat stand. I. Concept of stand structure. Agronomie $1: 207-216$.

McMaster, G.S., B. Klepper, R.W. Rickman, W.W. Wilhelm, and W. Willis. 1991. Simulation of aboveground vegetative development and growth of unstressed winter wheat. Ecol. Model. 53: 189-204.

Rickman, R.W., S. Waldman, and B.L. Klepper. 1996. MODwht3: A development driven winter wheat growth simulation. Agron. J. 88: 176-185.

Robertson, G.W. 1968. A biometeorological time scale for a cereal crop involving day and night temperatures and photo-period. Int. J. Biometeorol. 12:191-223.

Sweet, N., J.J.J. Wiltshire, and C.K. Baker. 1991. A new descriptive scale for early reproductive development in Lolium perenne $\mathrm{L}$. Grass Forage Sci. 46:201-206.

Thomson, W.J., and D.T. Stokes. 1987. The development of the barley ear. J. Biol. Educ. 21:17-27.

Waldren, R.P., and A.D. Flowerday. 1979. Growth stages and distribution of dry matter, N, P, and K in winter wheat. Agron. J. 71 391-397.

Wilhelm, W.W., G.S. McMaster, R.W. Rickman, and B. Klepper. 1993. Above-ground vegetative development and growth of winter wheat as influenced by nitrogen and water availability. Ecol. Model. 68:183-203.

Zadoks, J.C., T.T. Chang, and C.F. Konzak. 1974. A decimal code for the stages of cereals. Weed Res. 14:415-421. 